\title{
Vállalati fúziók engedélyezése Magyarországon
}

\author{
Rigó Csaba Balázs \\ Gazdasági Versenyhivatal \\ rigo.csaba@gvh.hu \\ Tóth András \\ Károli Gáspár Református Egyetem \\ toth.andras@kre.hu \\ Bodócsi András \\ Gazdasági Versenyhivatal \\ bodocsi.andras@gvh.hu \\ Buránszki Judit \\ Gazdasági Versenyhivatal \\ buranszki.judit@gvh.hu \\ Dudra Attila \\ Gazdasági Versenyhivatal \\ dudra.attila@gvh.hu
}

\begin{abstract}
ÖSSZEFOGLALÓ
Jelen tanulmány az eddigi legátfogóbb kutatás eredményeit mutatja be, amely a rendszerváltozással egyidős, 30 éves magyar fúzióengedélyezéssel kapcsolatban valaha született. A kutatás célja elsősorban az volt, hogy a magyarországi fúziók (vagy összefonódások) engedélyezésének elmúlt évtizedben elindult fejlesztését és annak közértéket képező hozadékait a szélesebb szakmai nyilvánosság elé tárja. A legfontosabb eredmény, hogy a 2010. évi adatokhoz képest a részletesebb elemzést igénylő fúziós eljárások átlagos ügyintézési ideje 2020-ra 62 százalékkal, a verseny szempontjából aggálymentes fúziókat vizsgáló ügyek elintézési ideje 82,5 százalékkal csökkent. A kutatás feltárta, hogy mára a Gazdasági Versenyhivatal fúziók kapcsán történő piaci beavatkozásainak harmada verbális formában történik. A kutatás a hatóság rendelkezésére álló adatok feldolgozásának és elemzésének módszertanával készült.
\end{abstract}

KulcsszavaK: versenyjog, összefonódás, fúziós trendek, közigazgatási eljárás, engedélyezés JEL-ко́Dок: G34, K42, K49

DOI: https://doi.org/10.35551/PSZ_2021_2_5 
Míg az 1990-es éveket a hazai versenyjog kereteinek kialakítása, a privatizáció támogatása, ${ }^{1}$ az EU-csatlakozásra felkészülés, a 2000es éveket az EU-csatlakozás, a piacgazdaságba való átmenet lezárása és a versenyjogi eszköztár „élesítése” jellemezte, addig a 2010-es évekre a gazdasági válságból való kilábalás és ezzel együtt a versenyfelügyeleti intézményrendszer hatékonyságának fejlesztése nyomta rá a bélyegét. Jelen tanulmányunkban ez utóbbit mutatjuk be a magyar fúzióengedélyezési rezsim kapcsán.

\section{A FÚZIÓK LÉNYEGE, GAZDASÁGRA GYAKOROLT HATASA}

A fúzió kifejezés lényegében egy gyűjtőfogalom. ${ }^{2}$ Fúzióról akkor beszélünk, ha

- önálló vállalkozások (vagy vállalkozás részek) összeolvadnak,

- egyik vállalkozás a másik fölött irányítási jogot szerez,

- közös vállalatot hoznak létre, vagy

- cégek valamely résztevékenységeiket önálló, közös vállalatba egyesítik, vagy akár

- eszközök (jogok, márkanév, szabadalom) megszerzése is beletartozhat a fogalomba, amennyiben azok önmagukban vagy a vállalkozás meglévő eszközeivel együtt elégségesek piaci tevékenység végzéséhez.

Számos konkrét fúzió bizonyította be, hogy tevékenységeik összekapcsolásával a vállalatok eredményesebben fejleszthetnek ki új termékeket vagy szolgáltatásokat, csökkenthetik a termelési, a logisztikai és a forgalmazási költségeket.

Az összefonódó vállalatok hatékonyabb müködésüknek köszönhetően a piaci verseny fokozódik, melynek nyertesei a fogyasztók, akik kedvezőbb árakon, jobb minőségű árukhoz és szolgáltatásokhoz juthatnak. A hatékonyság növelésén túl a fúzió elősegítheti azt is, hogy a vállalkozások nemzeti bajnokok lehessenek a saját területükön.
Egyes vállalatfúziók azonban vissza is foghatják a versenyt abban az esetben, amikor az érintett cégek erőfölényhez jutnak, vagy tovább erősítik a domináns piaci helyzetüket. Az ilyen esetekben az árak nagy valószínűséggel növekednek, csökken a választék, amely sérti a fogyasztók érdekeit. Ezzel el is érkeztünk ahhoz a ponthoz, amikor mind a kormányok, mind a részvényesek, mind a magánszemélyek - mint fogyasztók - ellenezhetik a fúziókat. Az erőfölénnyel való visszaélés megakadályozására, a kedvezőnek ítélt piacszerkezet fenntartására születtek meg az összefonódás-ellenőrzési jogszabályok, amelyek tartalmazzák a tervezett vállalat-összeolvadások kiértékelésének alapszabályait, valamint a végrehajtására vonatkozó eljárási szabályokat. Az összefonódás-ellenőrzéssel (fúziókontrollal) kapcsolatos feladatokat rendszerint az állami versenyhatóságokhoz (az Európai Unióban a tagállami versenyhatóságokhoz) telepítik, de az összefonódás-ellenőrzési rendelet feljogosítja az Európai Bizottságot is arra, hogy tiltsa azokat a vállalategyesítéseket és -felvásárlásokat, amelyek a verseny jelentős mértékű csökkenését idézhetik elő (Európai Bizottság, 2016).

Magyarországon a tisztességtelen piaci magatartás és a versenykorlátozás tilalmáról szóló 1996. évi LVII. törvény (a továbbiakban: Tpvt. vagy versenytörvény) VI. fejezetében foglalt összefonódás-ellenőrzési rendelkezések célja, hogy minden, a gazdaság szempontjából lényeges vállalategyesülést vagy felvásárlást (és egyéb irányításszerzést) versenyfelügyeleti ellenőrzés alá vonjon. A lényeges tranzakciók kiválasztására a Tpvt. alapvetően árbevételi adatokra építő szűrőrendszert alkalmaz: amennyiben az érintett vállalkozáscsoportok együttes nettó árbevétele eléri a 15 milliárd forintot, és ezen belül legalább két vállalkozáscsoport árbevétele meghaladja az 1 milliárd forintot, akkor az összefonódást a feleknek be kell jelenteniük. Abban az esetben, ha az érintett vállalkozáscsoportok együttes árbevétele 
nem éri el a 15 milliárd forintot, de meghaladja az 5 milliárd forintot, az adott tranzakciót akkor szükséges bejelenteni, ha valószínűsíthető, hogy az összefonódás káros hatással lehet a versenyre az érintett piacon.

A magyar nemzeti versenyhatóság, a Gazdasági Versenyhivatal (a továbbiakban: GVH) abban az esetben tiltja meg az összefonódást, ha az - különösen gazdasági erőfölény létrehozása vagy megerősítése következményeként - jelentős mértékben csökkenti a versenyt az érintett piacon (úgynevezett versenyhatásteszt). Ellenkező esetben a versenyre gyakorolt hatásokkal járó hatékonysági előnyök és hátrányok mérlegelése alapján az összefonódást tudomásul veszi a bejelentés alapján hatósági bizonyítvány kiadásával, vagy a bejelentés alapján hivatalból indított eljárás lezárásaként hozott határozatban. A GVH előzetes vagy utólagos feltételt, illetve kötelezettséget is előírhat az összefonódás hátrányos hatásainak mérséklése érdekében (például vállalkozásrészek, vagyontárgyak elidegenítésének tilalma, vagy valamely közvetett résztvevő felett gyakorolt irányítás megszüntetése).

A versenyre gyakorolt hatás szempontjából a versenykorlátozó hatás minősítésénél külön jelentőséggel bír, hogy az összefonódás versenytársak közötti (horizontális) vagy pedig eladó-vevő közötti (vertikális). A horizontális összefonódások általában közvetlenül a piaci szerkezet megváltoztatását okozzák, a vertikális összefonódások pedig a kapcsolódó piacokra hatnak negatívan. Egyes tranzakciók nem sorolhatók be egyértelműen egyik vagy másik csoportba annak következtében, hogy mind vertikális, mind horizontális jellemzőkkel bírnak. Előfordulhat olyan eset is, amikor nincs olyan piac, amelyen mindkét vállalat jelen van. Az ilyen összefonódásnak is lehetnek káros versenyhatásai. Portfolióhatásról beszélünk, ha egymást kiegészítő áruk gyártói, illetve forgalmazói (szomszédos piacok szereplői) kerülnek egy vállalkozáscsoporthoz. Ebben az esetben ugyanis, ha az egyik vállalkozáscsoport valamely áru(k) piacán magas piaci részesedéssel rendelkezik, akkor az összefonódás következtében bővülő vállalkozáscsoport más áru(k) piacán képes lehet versenykorlátozó stratégiák (például árukapcsolás) alkalmazására.

\section{A FÚZIÓS ELJÁRÁSREND MEGÚJIITÁSÁNAK ELÓZMÉNYEI, ÖSZTÖNZÖI}

A 2008-ban kirobbant gazdasági világválság általános recessziót eredményezett, a beruházási szándék csökkent, megtört a közvetlen külföldi tőkebefektetések tendenciája (KSH, 2010), amely a fúziók számát is visszavetette. A 20082009-es gazdasági világválságot követően a gazdaság fejlesztését segítő állami intézkedések kerültek a fókuszba. A válság mélypontját követően megindult gazdasági növekedés, amely a piaci tranzakciók számának emelkedésével járt és szükségszerűen érintette a GVH kontrollja alá eső fúziók számát is. A Központi Statisztikai Hivatal adatai (KSH, 2019) szerint a bruttó hazai termék (GDP) értéke 2010-től 2019el bezárólag kb. 73 százalékkal emelkedett, a GVH-hoz bejelentett összefonódások száma az elmúlt 10 évben szintén folyamatosan, bár valamivel kisebb mértékben, a 2010. évi adatokhoz képest a bejelentések száma 2020-ra 42 százalékkal nőtt. ${ }^{3}$ A bejelentett összefonódások számát a fúziós bejelentési küszöbszám emelése sem törte meg 2017-ben, amely arra utal, hogy gazdasági növekedés fokozta a vállalati összefonódási kedvet Magyarországon.

A Covid-világjárvány okozta gazdasági növekedés lassulása a GVH által vizsgált tranzakciók összetételére is hatással volt: a GVH-hoz bejelentett összefonódások kisebb vállalkozások feletti irányításszerzésre vonatkoztak (GVH, Gyorsjelentés 2020.) A gazdaság lassulása idején megfigyelhető ugyanis, hogy a vállalkozások jobban megfontolják a befektetéseiket, így a pénzügyi befektetők 
és a vállalkozások a kisebb és - a megtérülés szempontjából - kevésbé kockázatos vállalkozásokat keresnek felvásárlásaik célpontjaként. Emellett az elmúlt évek tapasztalatai arra utalnak, hogy különösen a pénzügyi befektetők, tőkealapok olyan akvizíciókat keresnek, amelyek valamilyen új technológia megszerzésére irányulnak, így a GVH esetében is jelentősen megnőtt azon összefonódások aránya, amelyek célja úgynevezett startupvállalkozásokba való pénzügyi befektetés volt, ezen cégek pedig jellemzően nem rendelkeznek még jelentős árbevétellel (Deloitte Riport, 2020).

$\mathrm{Az}$ a fúzióengedélyezési intézményrendszer, amely 2010 előtt a GVH-ban működött alkalmatlan lett volna a 2008-ban indult gazdasági válságból való kilábalás kezelésére. Az Európai Bíróság esetjoga is elismeri, hogy a versenyjogi ügyek elhúzódása károsan érintheti a befektetők pénzügyi érdekeit. ${ }^{4}$ Egyértelmű az összefüggés az adatok alapján a gazdaság növekedése és az összefonódások száma között. Mivel az adott ország fúzióengedélyezési rezsimje kihat a befektetők pénzügyi érdekeire, így annak hatékonysága egy növekedő gazdaságban, a befektetőkért folyó versenyben, alapvető fontosságú. Különösen igaz ez olyan nyitott gazdaságra, mint a magyar, amit az is mutat, hogy az egész EU-ban a magyar versenyhatóság alkalmazta harmadik legtöbbször az összes tagállam közül az EU versenyjogát GDP-arányosan (GVH, Gyorsjelentés 2020). Ehhez képest a GVH 2010-ben még $43 \mathrm{db}$ összefonódás-bejelentést intézett és azok 90 százalékát átlag 103 nap alatt kezelte. 2020ra a GVH $69 \mathrm{db}$ bejelentés mellett az ügyek 80 százalékában már átlag 4 nap alatt volt képes döntésre jutni. Meg kell jegyezni, hogy a fúzióengedélyezés egyfajta mintavételezés, ezért a hatékonysága három mutatón mérhető. Az egyik, hogy a problémamentes fúziókat milyen gyorsan engedi át, a másik, hogy az ehhez szükséges adatok mennyire hitelesek és megbízhatók, a harmadik (ezzel összefüggésben), hogy a problémás fúziókat sikerül-e azonosítani és a közérdek mentén kezelni. Jelen tanulmányban bemutatjuk, hogy miként került sor ezen elvárások teljesítésére a magyarországi fúzióengedélyezési eljárás fejlesztése során.

A válság utáni gazdaságpolitika a gazdasági növekedés támogatására törekedett, amit az állami működés párhuzamos átalakítása kísért. A versenyképesség javítása ebben az időszakban számos szerkezeti reform célja volt, felismerve, hogy a versenyképesség "nem alapulhat menynyiségi növekedésen, hanem csak minöségi fejlödésen, szerkezeti változáson." (Matolcsy, 2020, 21. oldal). A 2011-ben elindított közigazgatás-fejlesztési program ${ }^{5}$ célja az ügyfélközpontú, szolgáltató működés kialakítása, az eljárások egyszerüsítése, az ügyfélterhek csökkentése volt, amely program a vizsgált időszakban konkrét jogalkotási lépésekben ${ }^{6}$ is testet öltött. A GVH ennek jegyében 2011-ben a hatóság ügyfélbarát működésének stratégiai irányát jelölte ki, ennek keretében a hatóság ügyfélszolgálatának megújítása mellett belekezdett a fúziós eljárásrend fejlesztésébe, az eljárások kiszámíthatóságának és gyorsításának célját deklarálva. ${ }^{7}$ Megállapítható tehát, hogy a fúziós eljárásrend megújításának elindításához nem voltak elegendőek a GVH-ra - versenyszabályozási funkcióval bíró autonóm közigazgatási szervként ható általános fejlesztési ösztönzők, szükség volt a válság utáni speciális gazdasági helyzetre, az átfogó közigazgatási reform kezdeményezésére, ahogyan a hatóság helyzetfelismerésére és fejlesztés iránti elköteleződésére is.

$\mathrm{Az}$ 1. táblázat foglalja össze, hogy a magyar fúziós eljárásrendet érintően milyen fontosabb intézkedésekre került sor 2011-től kezdődően. ${ }^{8}$

A táblázatban jelzett - az adminisztratív terhek mérséklését, az átfutási idő rövidítését és a folyamat kiszámíthatóságának támogatását célzó - intézkedések végrehajtását a fokozatosság és a tanulságok keresése, hasznosítása jellemezte. Ennek köszönhetően érvényesült egyfajta ciklikusság mind az intézkedések tárgya, 


\section{A FÚZIÓS ELJÁRÁSRENDET ÉRINTŐ FONTOSABB INTÉZKEDÉSEK 2011-2020}

\begin{tabular}{|c|c|c|c|c|}
\hline \multicolumn{2}{|c|}{$\begin{array}{l}\text { Fúziós eljárásrendet érintő fontosabb intézkedések } \\
\text { 2011-2020 }\end{array}$} & $\begin{array}{l}\text { Vállalkozások } \\
\text { terheit } \\
\text { esökkentö }\end{array}$ & $\begin{array}{l}\text { Kiszámítható- } \\
\text { ságot és } \\
\text { átláthatósá- } \\
\text { got növeló }\end{array}$ & $\begin{array}{l}\text { Ügyintézést } \\
\text { gyorsító }\end{array}$ \\
\hline \multirow{2}{*}{2011} & Ürlap megújitása, nyilvános konzultációt követően & $x$ & $x$ & $x$ \\
\hline & Soft law kiegészítése: előzetes egyeztetésekről & $x$ & $x$ & $x$ \\
\hline \multirow{4}{*}{2012} & Fúziós Iroda - dedikált vizsgálati egység & & $x$ & $x$ \\
\hline & Úgynevezett egyszerűsített döntés alkalmazása & & $x$ & $x$ \\
\hline & Soft law kiegészitése (egyszerűsített döntésről) & & $x$ & \\
\hline & Bejelentett fúziók tényének honlapi közzététele & & $x$ & \\
\hline \multirow{3}{*}{2013} & $\begin{array}{l}\text { Soft law kiegészitése (kapcsolódó piaci részesedési } \\
\text { küszöb } 30 \text { százalékra emelése) }\end{array}$ & $x$ & $x$ & \\
\hline & Űrlap frissítése, összehangolása a közleményekkel & $x$ & $x$ & \\
\hline & $\begin{array}{l}\text { Törvénymódosítás (Tpvt.): 24/A. §, nemzetstratégiai } \\
\text { fúziók kormány általi mentesítési lehetősége }\end{array}$ & $x$ & & \\
\hline \multirow[t]{2}{*}{2014} & $\begin{array}{l}\text { Törvénymódositás (Tpvt.): végrehaitási tilalom } \\
\text { bevezetése, határidő-csökkentés, előzetes egyeztetés } \\
\text { törvényi szabályai }\end{array}$ & $x$ & & $x$ \\
\hline & Soft law kiegészitése & & $x$ & \\
\hline \multirow[b]{2}{*}{2015} & Törvénymódosítás (Tpvt.): részletszabályok & & $x$ & \\
\hline & $\begin{array}{l}\text { Soft law kiegészítése: egymással összefüggő ügyletek } \\
\text { kezeléséról }\end{array}$ & & $x$ & \\
\hline \multirow[b]{2}{*}{2016} & Törvénymódosítás (Ket.): sommás eljárás & $x$ & & $x$ \\
\hline & $\begin{array}{l}\text { 2017-től módosuló Tpvt. alkalmazására való felkészülés, } \\
\text { űrlapmódositás }\end{array}$ & & $x$ & \\
\hline \multirow{3}{*}{2017} & $\begin{array}{l}\text { Törvénymódosítás (Tpvt.): bejelentéses rezsim, } \\
\text { küszöbszámemelés, önkéntes küszöb, díjcsökkentés, } \\
\text { határidő-csökkentés, az értesítés nélküli helyszíni } \\
\text { kutatás lehetősége }\end{array}$ & $x$ & & $x$ \\
\hline & Fúziós Iroda a Versenytanács irányitása alatt & & $x$ & $x$ \\
\hline & $\begin{array}{l}\text { Soft law kiegészítése (például egységes jogalkalmazási } \\
\text { közlemény) }\end{array}$ & & $x$ & \\
\hline \multirow[t]{2}{*}{2018} & $\begin{array}{l}\text { Összefonódás-bejelentési ûrlap elektronikus } \\
\text { benyújtásának lehetősége, űrlap frissítése }\end{array}$ & $x$ & & $x$ \\
\hline & Soft law kiegészitése & & $x$ & \\
\hline
\end{tabular}




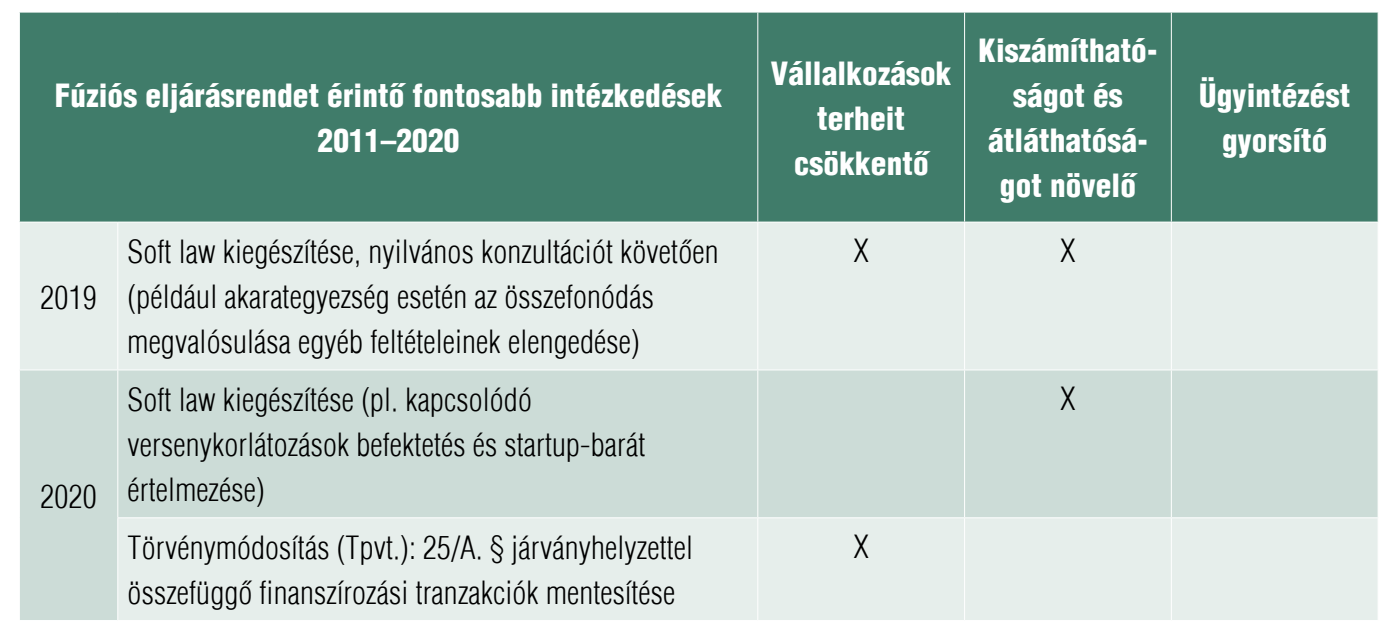

Forrás: saját szerkesztés

mind azok választott módszerei tekintetében. Így a hatóság az eljárásrendjét meghatározó egyes elemekhez több körben (mint a vállalkozások felé támasztott adatigényt meghatározó ürlap) vagy rendszeresen (mint a joggyakorlatot kiszámíthatóvá tevő soft law) vissza-visszatért, ahogyan egymást váltották a szabályozási kereteken belüli fejlesztési teret kihasználó és a kereteket megváltoztató intézkedések, illetve a folyamat- és a szervezetfejlesztési jellegü lépések is.

Az eljárásrend 2011-től megkezdett átalakításának legjelentősebb lépését a Tpvt. 2017. január 15-től hatályos változása hozta. Ekkor került bevezetésre a bejelentéses rendszer, amely lényege, hogy nem minden összefonódás-bejelentés alapján indul versenyfelügyeleti eljárás, mint a korábbi kérelmes rezsimben, hanem csak abban az esetben

- ha az összefonódás felveti a verseny jelentős mértékű csökkenésének lehetőségét (ekkor úgynevezett teljes körű vagy II. fázisú eljárás indul, 4 hónapos határidővel), vagy

- ha a benyújtott ürlap nem tartalmaz a versenyhatások értékeléséhez szükséges minden információt (ekkor úgynevezett egyszerűsített, vagy I. fázisú eljárás indul, 30 napos határidővel).
Azon fúziókat, amelyek értékeléséhez minden űrlapban elvárt információt a GVH rendelkezésére bocsátottak, és azok a piaci verseny szempontjából nyilvánvalóan aggálymentesek, a GVH hatósági bizonyítvánnyal veszi tudomásul és engedi végrehajtani. Az eljárás indításáról vagy a hatósági bizonyítvány kiadásáról a GVH-nak a bejelentést követő 8 napon belül kell döntenie.

\section{A MAGYARORSZÁGI FÚZIÓK JELLEMZŐ ADATAI}

Mivel a Tpvt. alapján csak a törvényben meghatározott küszöbszámokat teljesítő összefonódásokat kell a vállalkozásoknak bejelenteni, a GVH által vizsgált összefonódások természetesen nem adhatnak teljes képet a magyarországi felvásárlások egészéről. Mindazonáltal bizonyos tendenciák megfigyelhetők az adatok alapján, hiszen a jelentősebb összefonódások a GVH látókörébe kerülnek.

A gazdaságot érintő változások közül azösszefonódások ellenőrzése szempontjából kiemelkedő jelentőséggel bír, hogy 2010-től lényegesen megváltozott a magyar gazdaságpolitika addigi, az állami tulajdont a magántulajdon- 
hoz képest eredendően hátrányosnak minősítő szemlélete. Ennek nem egyszerüen az lett a következménye, hogy 2010 után már nem történtek érdemi privatizációs lépések, hanem az is, hogy az állam irányítást biztosító többségi tulajdont szerzett mindenekelőtt a közszolgáltatások területén és a bankszektorban a korábban (nemegyszer túlhajtottan) privatizált vállalkozásokban, ami összefonódásnak minősült. A felsoroltak eredményeként a GVH által 2020-ban vizsgálat alá vont összefonódások 30 százaléka állami érintettséggel bíró irányításszerzés volt. A GVH által a 2012 és 2020 közötti időszakban vizsgált összefonódások közül az állami érintettségű fúziók arányát $a z 1$. ábra követi nyomon.

Ezeknek a felvásárlásoknak a jelentős részét azonban olyan összefonódások jelentik, ahol egy állami tulajdonban lévő tőkealap szerzett befektetési céllal - jellemzően más vállalkozással közös - irányítást egy, még a piacra lépés előtt álló vagy a piacra való belépés korai szakaszában lévő úgynevezett startupvállalkozás felett. A startupvállalkozások feletti irányításszerzések - az állami szerepvállalástól függetlenül - is jelentős szerepet töltenek be napjaink gazdaságában. A startupokat érintő összefonódások GVH által vizsgált összefonódásokhoz viszonyítva arányát a 2. ábra mutatja.

Ezekről a tranzakciókról azonban elmondható, hogy eddig még nem került a GVH látókörébe olyan ügy, amely a GVH részletes vizsgálatát igényelte volna.

Bár az utóbbi években ismét megnövekedett azon tranzakciók száma, és aránya, amelyek során külföldi vállalkozások korábban

\section{AZ ÁLLAMI ÉRINTETTSÉGÚ FÚZIÓK ARÁNYA A GVH ÁLTAL VIZSGÁLT ÖSSZEFONÓDÁSOK KÖZÖTT}

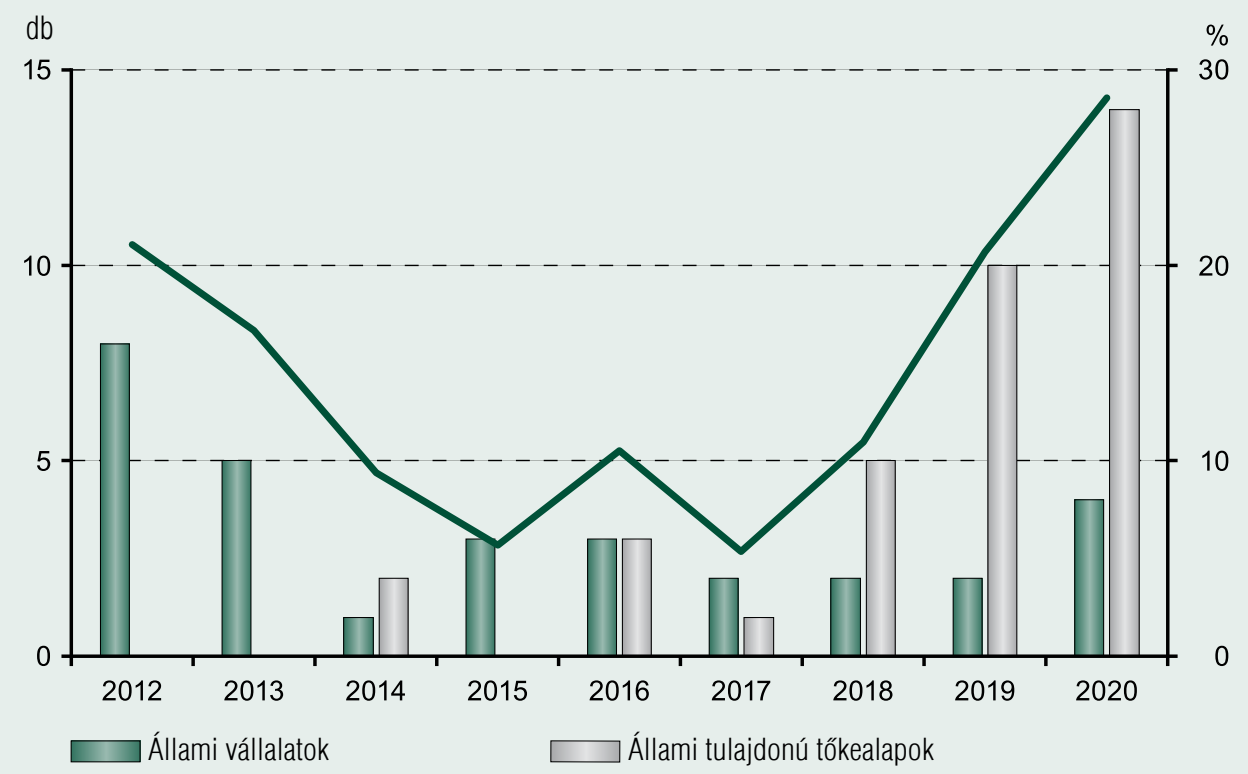

Forrás: saját szerkesztés 


\section{A STARTUPOKAT ÉRINTŐ ÖSSZEFONÓDÁSOK ARÁNYA A GVH ÁLTAL VIZSGÁLT ÖSSZEFONÓDÁSOKHOZ VISZONYÍTVA}

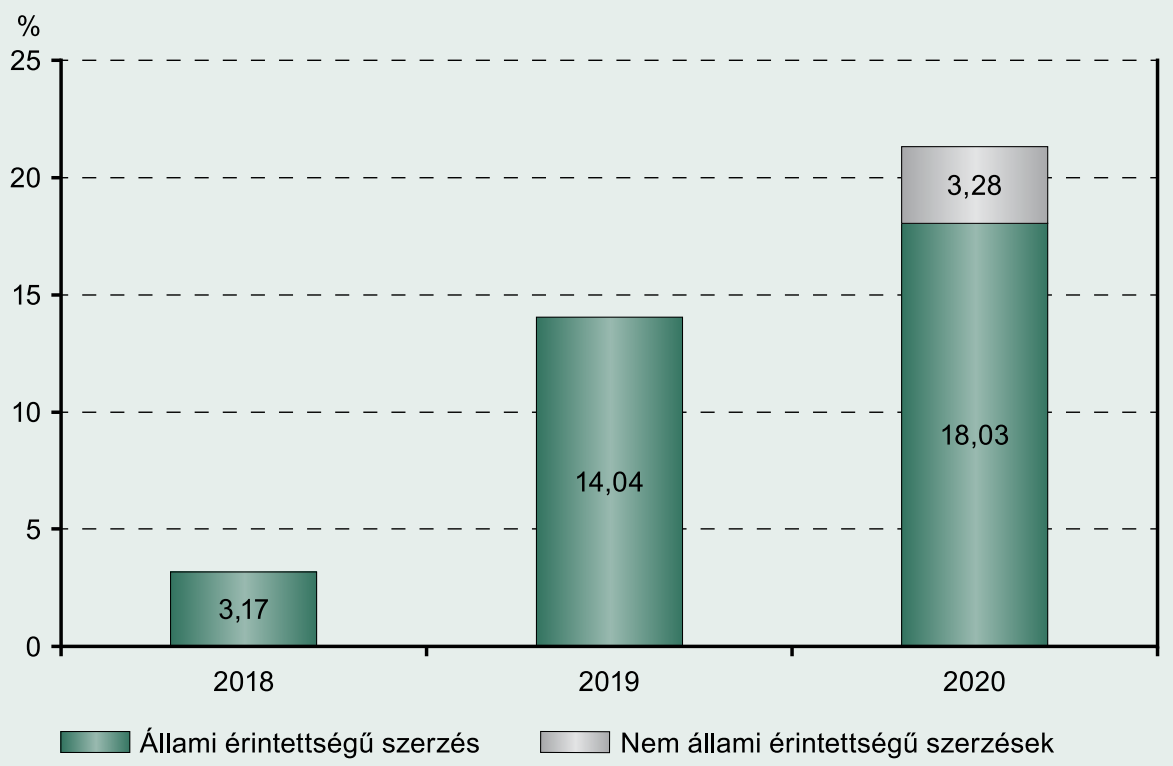

Forrás: saját szerkesztés

magyar tulajdonban lévő vállalkozásokat vásároltak fel, ezek aránya csökkenést mutat a 2011. évi adatokhoz képest. A külföldi szerzések közül, azon tranzakciók aránya, amelyek során a külföldi vállalkozás magyar tulajdonban lévő vállalkozás felett szerzett irányítást, az elmúlt 10 évben átlagosan 10 százalék volt (lásd 3. ábra).

A GVH által vizsgált összefonódások - változó intenzitással - a nemzetgazdaság számos ágát érintették. Különösen magas a feldolgozóipart érintő összefonódások száma. Ezen belül a fúziók nagy része az autóipar, az élelmiszeripar, a vegyipar, a gyógyszeripar, valamint a csomagolóanyag-gyártás szektorát érintette (lásd 4. ábra).

$\mathrm{Az}$ energiaszektort érintő összefonódások száma továbbra is magasnak tekinthető, annak ellenére, hogy - amint az a következő pontban ismertetésre kerül - a szektorban több összefonódást a kormány nemzetstratégiai jelentőségűnek minősített, így azokat végül nem kellett a vállalkozásoknak bejelenteniük a GVH-hoz. Az ingatlanszektort érintő összefonódások folyamatosan jelen vannak a GVH gyakorlatában, azonban a piac részletes vizsgálatára egyik összefonódás kapcsán sem került sor. Az információ-, kommunikációszektort érintő ügyek nagy száma a digitalizálódó világunkban nem meglepő, és amint arra már utaltunk a szektorban működő különböző startupokba történő befektetések növekvő száma is hozzájárul ahhoz, hogy egyre több, ebbe a szektorba tartozó összefonódást vizsgál a GVH. A szektort érintő összefonódások száma a jövőben várhatóan tovább fog emelkedni.

A Tpvt. 2013. novemberi módosítása teremtette meg annak lehetőségét, hogy 


\section{A KÜLFÖLDI FELVÁSÁRLÁSOK ARÁNYA A GVH ÁLTAL VIZSGÁLT ÖSSZES ÖSSZEFONÓDÁSHOZ VISZONYÍTVA}

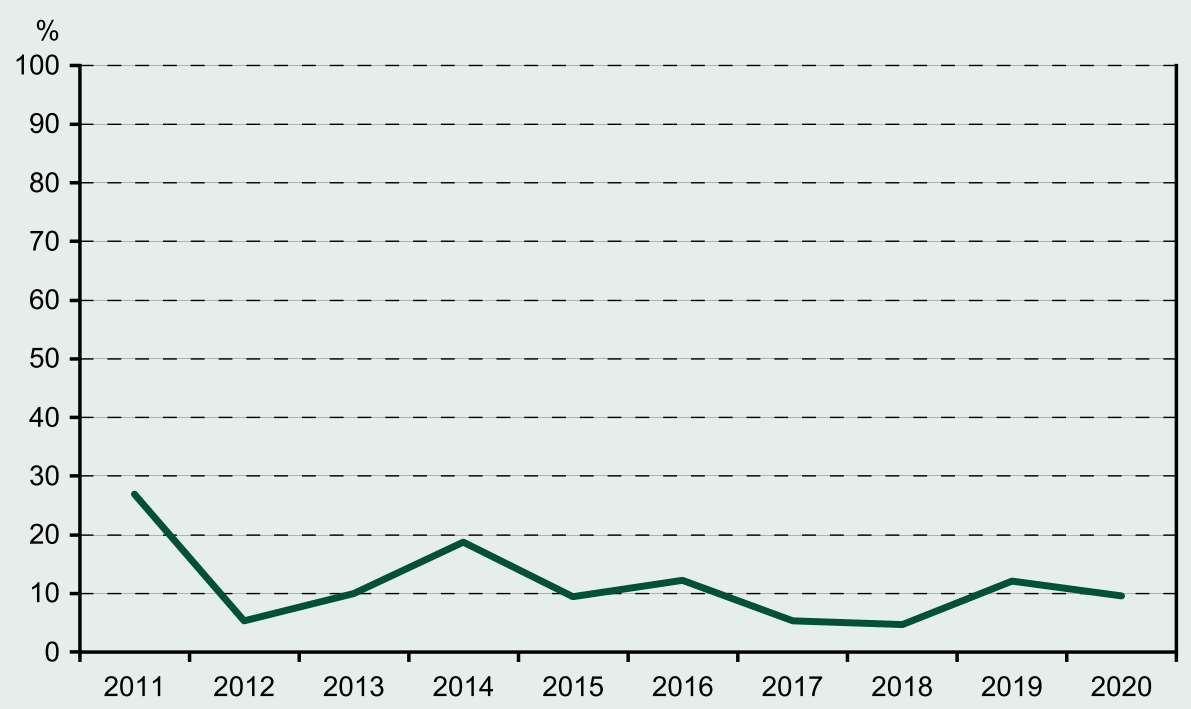

a kormányrendelettel a vállalkozások összefonódását közérdekből nemzetstratégiai jelentőségűnek minősítheti, amely esetben a vállalkozásoknak azt nem kell bejelenteniük a GVH-hoz. Ezzel a lehetőséggel a kormány 2020 végéig 31 alkalommal élt, a legtöbb ilyen tárgyú kormányrendelet (összesen 12) 2014ben született. A 2014. évet követően a nemzetstratégiai jelentőségűvé nyilvánított összefonódások száma jelentősen csökkent, 2015 és 2020 közötti időszakot nézve, évente átlagosan 3 összefonódást minősített a kormány nemzetstratégiai jelentőségűnek. A nemzetstratégiai jelentőségű összefonódások számának alakulását mutatja az 5. ábra.

A szektorok közül kiemelkedik az energiaszektor, a 31 nemzetstratégiai jelentőségü öszszefonódásból 13 ezt a szektort érintette, amint azt 6. ábrán láthatjuk.

\section{AZ ELMÚLT IDŐSZAK LEGFONTOSABB TANULSÁGAI}

Ahogyan bemutatásra került, a GVH az elmúlt 10 évben kiemelten kezelte és folyamatosan fejlesztette az összefonódások ellenőrzésével kapcsolatos eljárásrendjét. Ennek legfontosabb lépései már bemutatásra kerültek, a jelen fejezet célja így ezen folyamat legfontosabb tapasztalatainak, eredményeinek összefoglalása.

\section{ELŐZETES EGYEZTETÉSEK SZEREPÉNEK FELÉRTÉKELÓDÉSE}

Az összefonódás-bejelentési rezsimben az öszszefonódás-bejelentéssel kapcsolatos eljárás legfontosabb feladata az aggálymentes fúziók hatékony szürésének biztosítása, amely viszont 


\section{AZ ÖSSZEFONÓDÁSOK SZEKTOROK SZERINTI MEGOSZLÁSA}

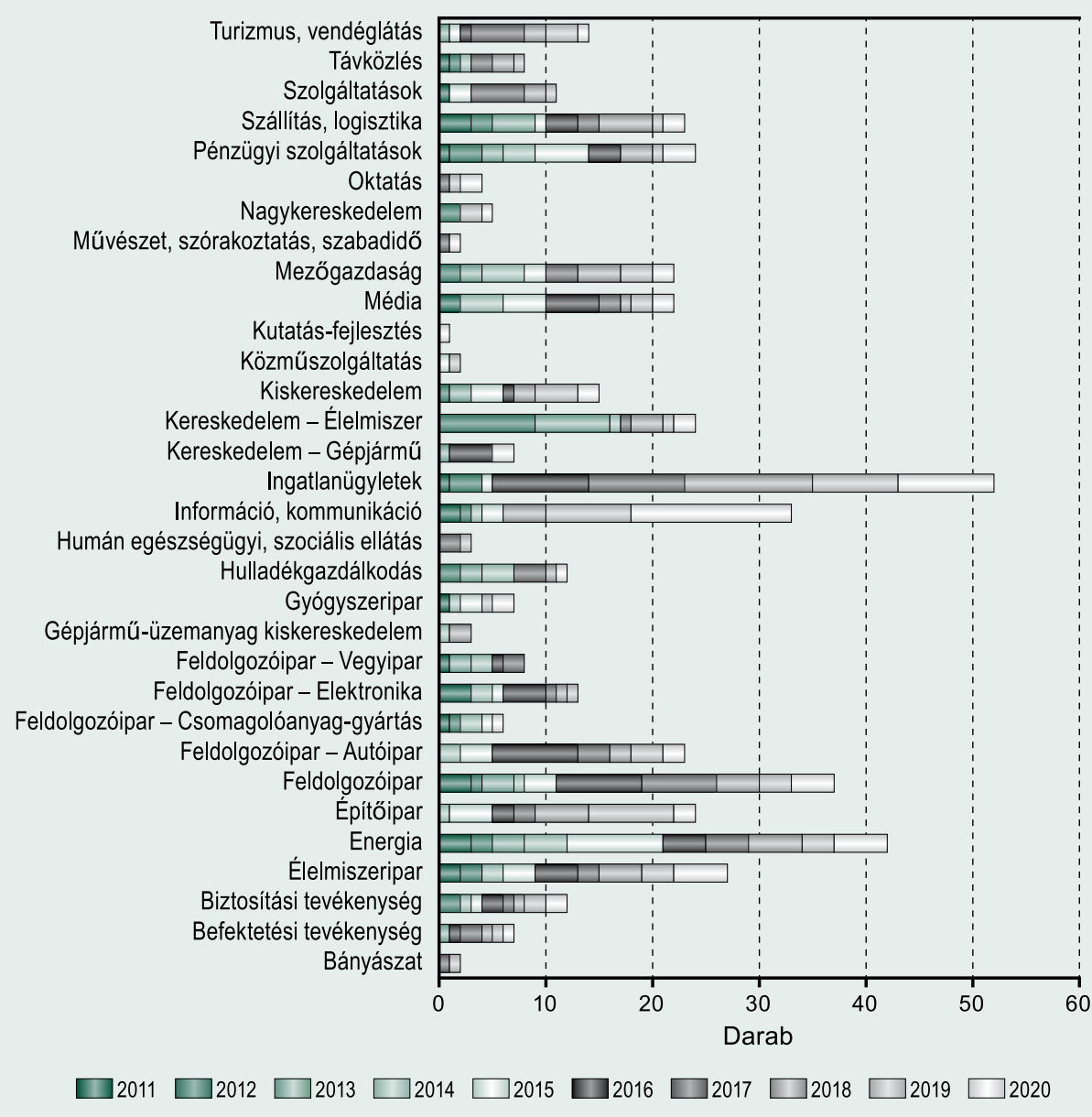

Forrás: saját szerkesztés

feltételezi egy jól működő előzetes egyeztetési (prenotifikációs) rendszer működését. ${ }^{9}$ Ennek során a GVH vizsgálói rámutathatnak a bejelentési űrlap hiányosságaira, jelezhetik, hogy milyen további információk és elemzések szükségesek ahhoz, hogy a káros versenyhatások nyilvánvaló hiánya kérdésében döntést lehessen hozni, így a problémamentes összefonódásokat hatósági bizonyítvány kiadásával le lehessen zárni. Mindez jelentős szerepet játszott abban is, hogy a bejelentések döntő hányada hatósági bizonyítvány kiadásával zárul, és az összefonódás-bejelentési eljárások kapcsán hozott döntéseket tekintve az I. fázisú eljárásindítások aránya jelentősen csökkent 2017 óta, amellyel párhuzamosan viszont megnőtt a hatósági bizonyítványok aránya (lásd 7. ábra).

$\mathrm{Az}$ adatok kapcsán fontos kiemelni, hogy az előzetes egyeztetések jellegükből is fakadóan elsősorban az I. fázisú ügyindítások elkerü- 
NEMZETSTRATÉGIAI JELENTŐSÉGŨ ÖSSZEFONÓDÁSOK SZÁMÁNAK ALAKULÁSA

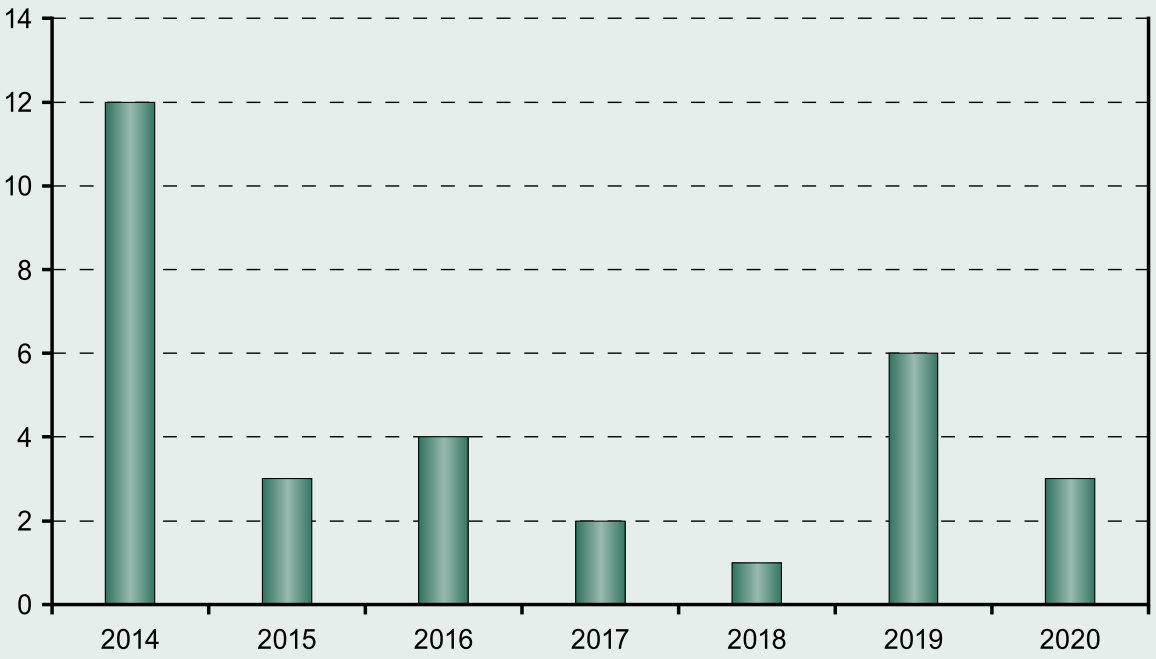

Forrás: saját szerkesztés

6. ábra

\section{NEMZETSTRATÉGIAI JELENTŐSÉGŨ ÖSSZEFONÓDÁSOK SZEKTOROK SZERINTI MEGOSZLÁSA}

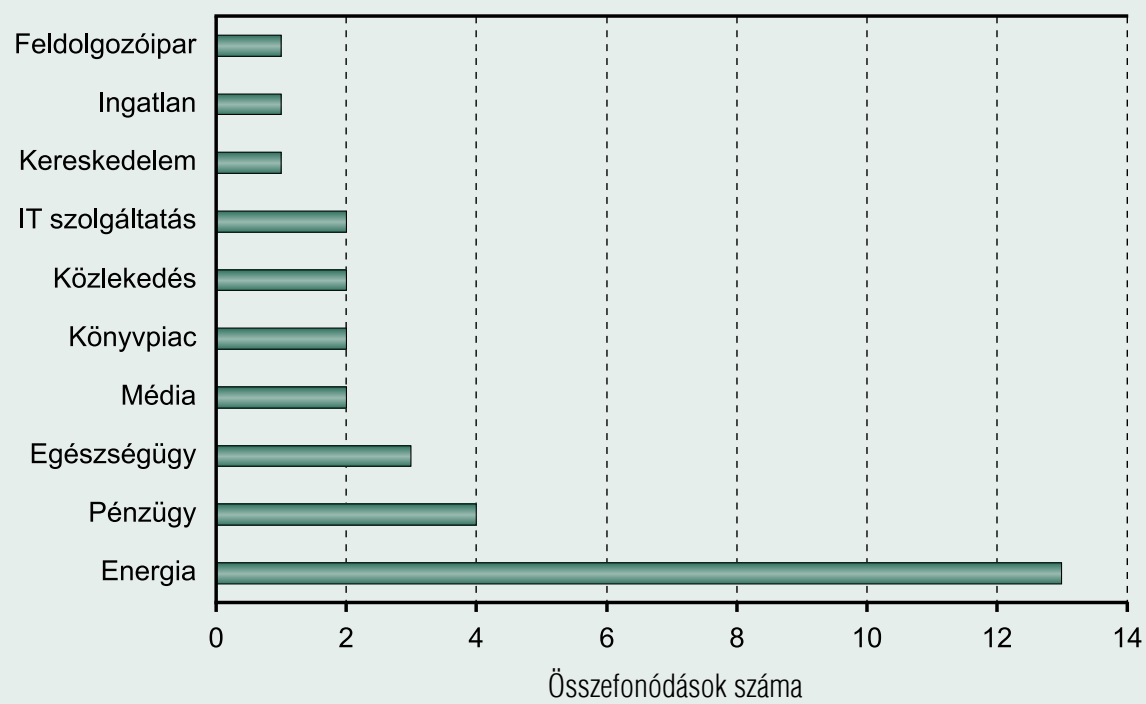

Forrás: saját szerkesztés 


\section{AZ ÖSSZEFONÓDÁS-BEJELENTÉSEK KIMENETELE 2017-2020}

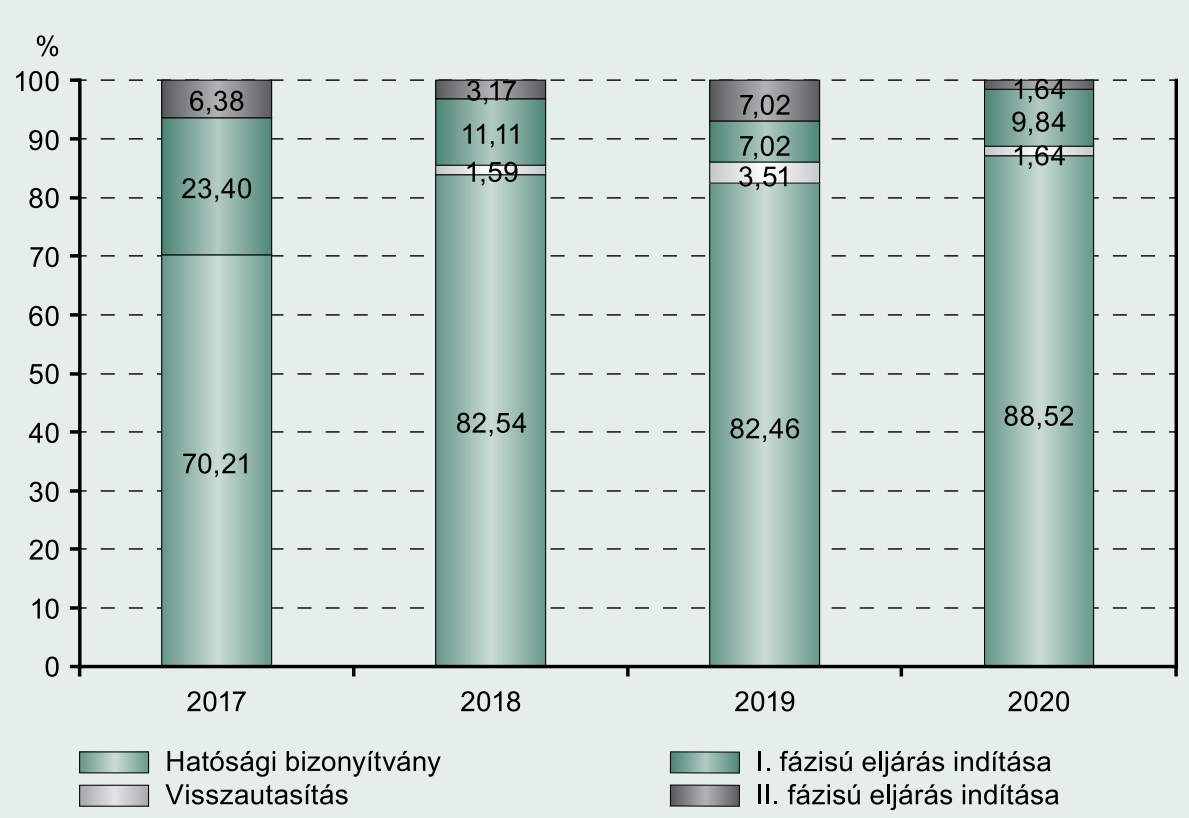

Forrás: saját szerkesztés

lését teszik lehetővé, ebből következően az eljárások számának csökkenése ezen ügytípus esetében jelentősebb, mint a II. fázisú, részletesebb vizsgálatot igénylő ügyeknél. Mindazonáltal bizonyos körülmények között az előzetes egyeztetések II. fázisú eljárás megindítását is elkerülhetővé tehetik, erre részletesebben a verbális intervenciók kapcsán térünk ki.

Emellett nem minden esetben alkalmas az előzetes egyeztetés arra, hogy elkerülhető legyen az I. fázisú eljárás megindítása. Mindezek mellett is elmondható, hogy az előzetes egyeztetések révén jelentősen csökkenthető az elkerülhető eljárások megindításának kockázata, amit jól mutat, hogy 2020-ban a prenotifikált ügyek 7 százalékában került sor ügyindításra (ez a teljes körű ügyeket is tartalmazza), míg a nem prenotifikált ügyek esetében ugyanez az arány 43 százalék volt. Az ügyindítások százalé- kos megoszlását prenotifikált és prenotifikáció nélküli ügyekben a 8. ábra tartalmazza.

\section{ADATHITELESSÉG, A FÚZIÓKHOZ KAPCSOLÓDÓ JOGSÉRTÉSEK ELLENI HATÉKONY FELLÉPÉS}

Az eljárások gyorsabb elintézése mellett ugyanakkor a GVH továbbra is fokozott figyelmet szentel az adathitelességnek. Az ügyintézési határidők a felek számára kedvező csökkenése nem mehet a közérdek rovására. Ezért a megtévesztő információk nyújtásával megvalósított jogsértésekkel szembeni fellépést biztosító szankciórendszer fontos eszköz annak érdekében, hogy a GVH képes legyen teljesíteni törvényi kötelezettségeit, azaz szigorú és átfogó vizsgálatokat folytasson le a fogyasztók ér- 


\section{ÜGYINDÍTÁSOK SZÁZALÉKOS MEGOSZLÁSA PRENOTIFIKÁLT ÉS PRENOTIFIKÁCIÓ NÉLKÜLI ÜGYEK TEKINTETÉBEN, 2020}

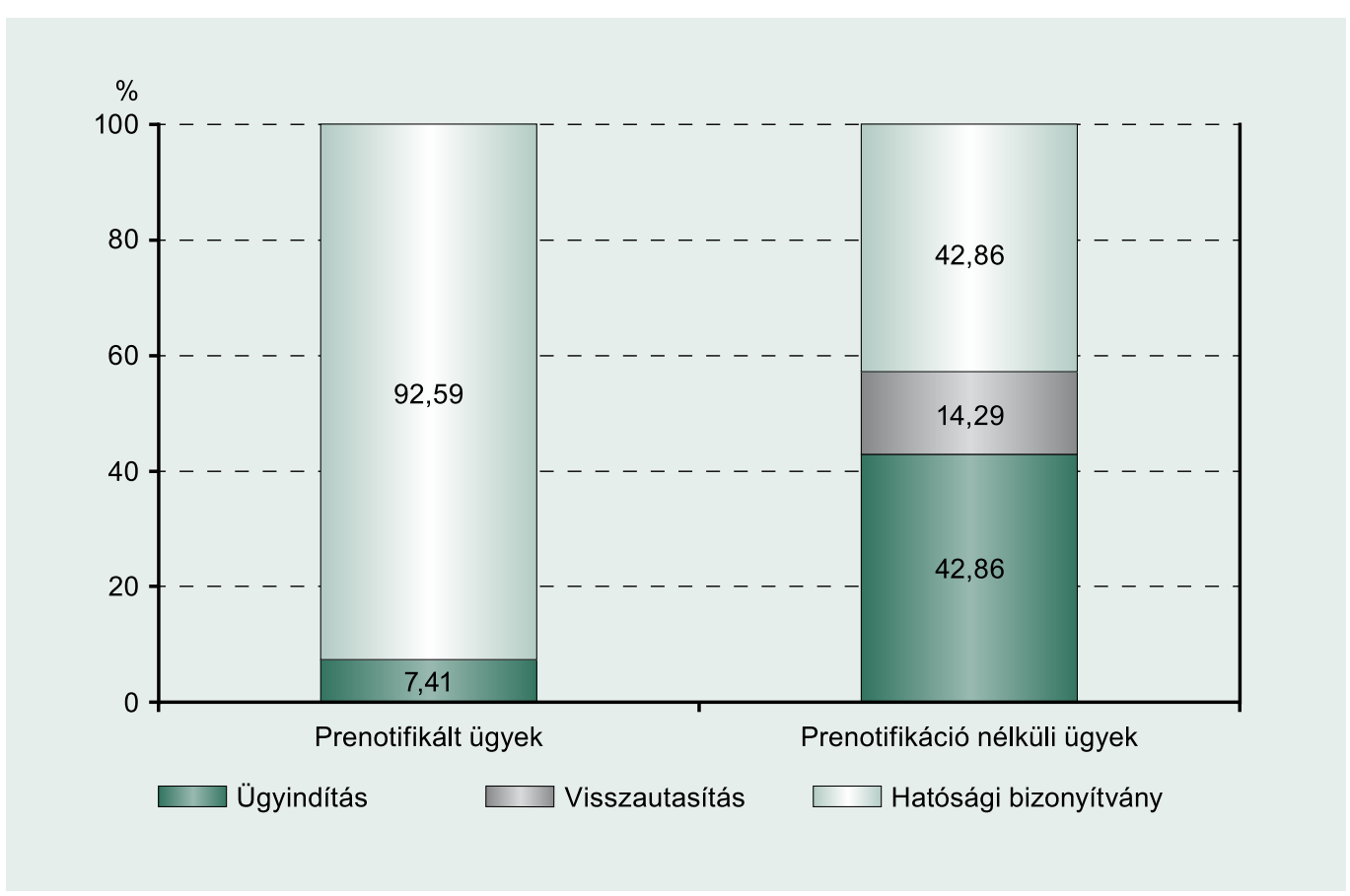

Forrás: saját szerkesztés

dekében. Az összefonódás vizsgálatára irányuló eljárások ugyanis nagyban építenek az ügyfelek együttműködésére, hiszen alapvetően a vállalkozások vannak az egyes adatok birtokában. Az eljárás lefolytatása során az ügyfeleket ezért fokozott felelősség terheli, hogy a GVH számára részletes és teljes körü adatokat szolgáltassanak az összefonódás vizsgálatához szükséges valamennyi releváns tényről. ${ }^{10}$

A megtévesztő információközléssel szembeni fellépés az elmúlt években a GVH gyakorlatában jelentős figyelmet kapott. A GVH 2017 elején két ügyben ${ }^{11}$ is arra kényszerült, hogy visszavonja az összefonódást engedélyező határozatát, és a két ügyben közel 83 millió forint eljárási bírságot is kiszabott az összefonódás engedélyezését kérő vállalkozásokra. Emellett a GVH egy további ügyben - önálló eljárásban
- 45 millió forint bírságot szabott ki. ${ }^{12}$ Összességében tehát megtévesztő információközléssel kapcsolatos eljárásokban a GVH eddig közel 128 millió forint bírságot szabott ki.

Megjegyzendő, hogy az adathitelesség biztosítása kapcsán a határozat visszavonása mellett további eljárási lehetőségek is a GVH rendelkezésére állnak. Egyrészt az adathitelesség biztosításának fontos eszköze, hogy a GVHnak 2017 óta lehetősége van arra, hogy előzetes értesítés nélküli helyszíni kutatást (úgynevezett hajnali rajtatütést) foganatosítson fúziós ügyekben, az összefonódás-bejelentésben lényeges tény félrevezető közlésének valószínűsíthetősége esetén. Ezzel a lehetőséggel eddig a GVH egy ügyben ${ }^{13}$ élt. Amennyiben a félrevezető közlés az összefonódás szempontjából nem lényeges tényre vonatkozik - így a hatá- 
rozat visszavonásának törvényi feltételei ${ }^{14}$ nem teljesülnek - úgy eljárási bírság kiszabásának lehet helye.

A fúziókkal összefüggő jogsértések másik esete az összefonódásnak a GVH tudomásulvétele előtti végrehajtása. A végrehajtási tilalom intézményét 2014. július 1 -jével vezette be a jogalkotó a Tpvt.-be, a lényege, hogy az árbevételi küszöbszámok alapján bejelentésköteles tranzakciók nem hajthatók végre a GVH hozzájárulása nélkül, ha erre mégis sor kerül, akkor az bírsággal szankcionálható (és indokolt esetben - jelentős versenyaggályok felmerülésekor - a fúzió előtti állapot helyreállítása is előírható). 2014 óta a GVH összesen 9 tranzakció $^{15}$ kapcsán állapította meg a végrehajtási tilalom megsértését, és összesen közel 42 millió forint bírságot szabott ki. Valamenynyi ügyben a felek - miután észlelték a jogsértést - maguk jelentették be az összefonódást a GVH-hoz, és a GVH egyik fúzió esetében sem azonosított versenyaggályt. Ezen körülményeket is figyelembe véve - továbbá mivel visszaesés (a végrehajtási tilalom korábbi megsértése) egyik esetben sem volt megállapítható, és jellemzően rövid idő telt el a tranzakció végrehajtása és annak a GVH részére történő bejelentése között - a GVH jellemzően a Tpvt. szerinti bírság minimumához közeli összeget szabott ki az érintett vállalkozásoknak.

A végrehajtási tilalom bevezetését megelözően a Tpvt. az összefonódás iránti kérelmek benyújtására a tranzakció létrejöttétől számítva harminc napos határidőt állapított meg, ezen határidő be nem tartása, illetve a kérelem elmulasztása miatt 2010 és 2014 . között a GVH összesen 180 millió forint bírságot szabott ki.

Összességében a GVH 2010 óta összesen 350 millió forint bírságot szabott ki a vállalkozásokkal szemben fúziókhoz kapcsolódó jogsértések miatt, és ezen belül is kiemelt figyelmet szentel az adathitelességgel kapcsolatos jogsértéseknek: a fúziós jogsértésekért ki- szabott bírságok 36,5 százalékát, közel 128 millió forintot a GVH megtévesztő információközlés miatt szabta ki a vállalkozásokra (lásd 9. ábra).

\section{BEAVATKOZÁSOK}

A Tpvt. lehetővé teszi a GVH számára, hogy a versenyproblémákat felvető összefonódások esetében, annak megtiltása helyett az összefonódás hátrányos hatásainak mérséklése érdekében határozatában előzetes vagy utólagos feltételt, illetve kötelezettséget írjon elő. Az ilyen korrekciós intézkedések, melyek kizárólag az érintett vállalkozás vállalása alapján hozhatók, két fö csoportba sorolhatók. Az egyik csoportot az úgynevezett strukturális beavatkozások alkotják, míg a másikba a magatartási előírásokat sorolhatjuk, ugyanakkor lehetnek olyan megoldások is, amelyek strukturális és magatartási jelleggel is bírnak. ${ }^{16}$ A strukturális feltételek és kötelezettségek olyan intézkedések, amelyek a piac szerkezetére irányulnak, míg a magatartási kötelezettségvállalások az öszszefonódás résztvevőinek tulajdonjogát korlátozzák. A különböző típusú vállalásokat gyakran kiegészítik különböző információs jellegü, a vállalás teljesítésére vonatkozó tájékoztatási jellegű kötelezések, illetve a vállalás teljesítését ellenőrző (úgynevezett ellenőrzőbiztos) alkalmazása.

A magyar és a nemzetközi tapasztalat is az, hogy az engedélyezés alá vont tranzakciók kis része indokol beavatkozást (bármilyen korrekciós intézkedést), a tiltások száma pedig kifejezetten elenyésző. ${ }^{17}$

A GVH 2010 óta összesen 10 tranzakció esetében látta szükségesnek valamilyen korrekciós intézkedés alkalmazását, illetve 1 tranzakció esetében került sor tiltásra a GVH-t kötő tiltó szakhatósági állásfoglalás miatt ${ }^{18}$ (ezek együttesét tekintjük beavatkozásnak, lásd 10 . ábra). 


\section{A BÍRSÁGKISZABÁSRA OKOT ADÓ FÚZIÓKKAL KAPCSOLATOS JOGSÉRTÉSEK SZÁZALÉKOS MEGOSZLÁSA}

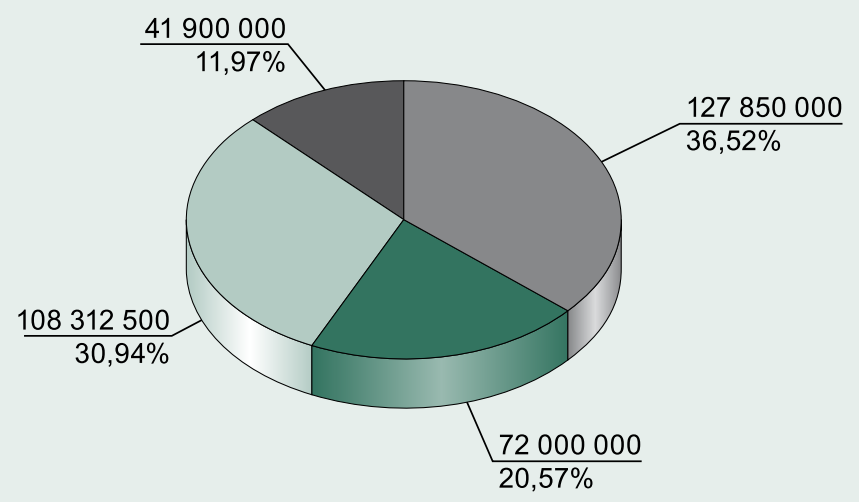

$\square$ Megtévesztő információközlés
Késedelmes benyújtás
Engedélykérés elmulasztása
Végrehajtási tilalom megsértése

\section{FÚZIÓS BEAVATKOZÁSOK SZÁMA 2010 ÓTA}

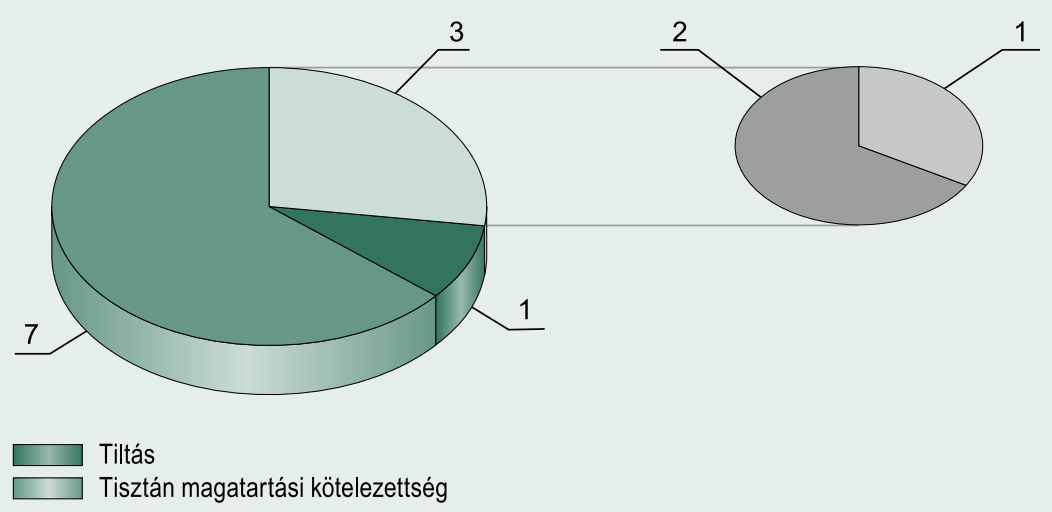

Hibrid (strukturális és magatartási kötelezettség) ellenőrző biztossal

Hibrid (strukturális és magatartási kötelezettség) ellenőrző biztos nélkül 
A formális beavatkozások mellett a GVH gyakorlatában egyre nagyobb súllyal jelennek meg azok a beavatkozások is, amelyek esetében - formális, határozatban történő - előírás nélkül kerül egy versenyprobléma orvoslásra. A formális beavatkozással érintett szektorokat mutatja a 11. ábra.

Ezen belül két nagyobb csoport különíthető el: az első csoportot azok a beavatkozások alkotják, amelyek esetében a tranzakció hatásaként felmerülő versenyprobléma került orvoslásra, míg a második körbe az úgynevezett nem kapcsolódó versenykorlátozások ${ }^{19}$ kezelése tartozik. Az előzetes egyeztetések szerepe mindkét típus esetében döntő jelentőségü, hiszen az aggályok jellemzően már az egyeztetés ezen szakaszában jelzésre kerülnek, lehetővé téve a felek számára azt, hogy adott esetben a benyújtást megelőzően megtehessék azokat a szükséges intézkedéseket, amelyek révén elkerülhető lehet egy hosszabb és időigényesebb versenyfelügyeleti eljárás.

Az elmúlt években egy olyan tranzakció volt, ahol a GVH-nak az előzetes egyeztetés során jelzett aggályaira tekintettel a felek végül elálltak a tranzakciótól. Emellett két összefonódás esetében az eljárás lefolytatásra került, azonban miután a GVH jelezte az érintett vállalkozások számára, hogy az összefonódás tiltását tervezi, a felek végül úgy döntöttek elállnak a tranzakciótól és visszavonták a kérelmüket.

Emellett két esetben a GVH szóbeli jelzései lehetővé tették azt, hogy a felek elkerülhessenek egy hosszabb, időigényesebb eljárást, így végül formális beavatkozásokra ezekben az ügyekben nem került sor. Egy esetben ugyanis a felek az előzetes egyeztetés során jelzett aggályokra is figyelemmel úgy döntöttek, hogy a versenyaggályt felvető terméket, még a bejelentést megelőzően értékesítik, kiküszöbölve

\section{FORMÁLIS BEAVATKOZÁSSAL ÉRINTETT SZEKTOROK}

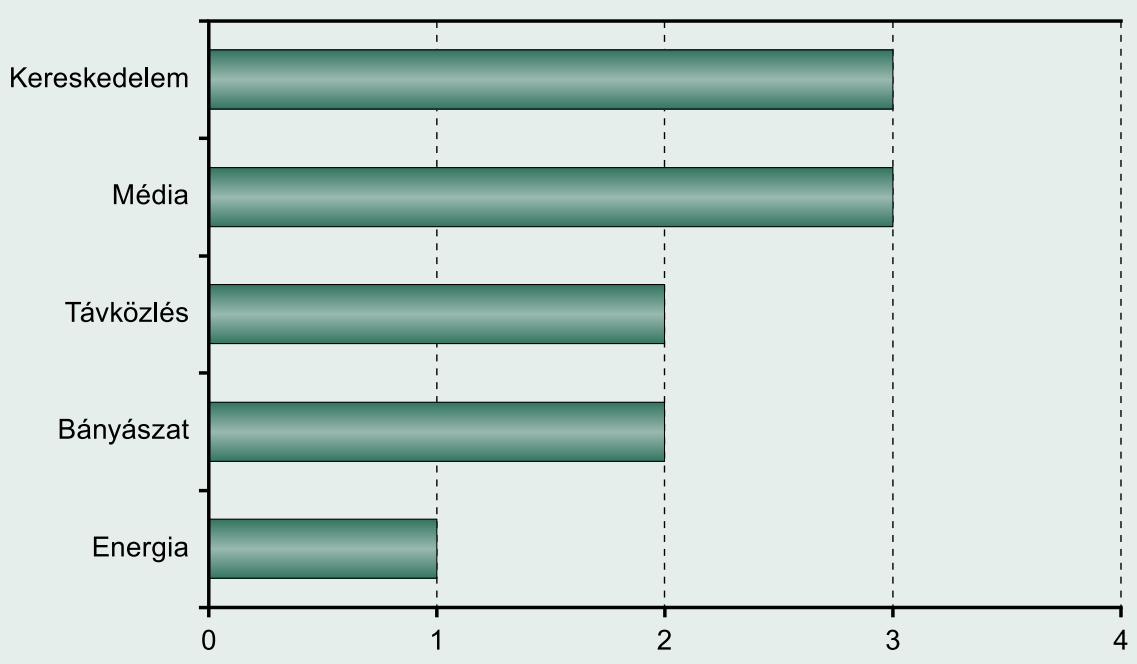


ezzel a versenyproblémát. ${ }^{20}$ Egy további ügyben pedig a vizsgálatnak az eljárás teljes körűvé nyilvánítását megelőző egyeztetésen elhangzott aggályaira figyelemmel, a felek úgy határoztak, hogy az esetlegesen versenyproblémát jelentő, általuk működtetett rádióadókat értékesítik egy független vevő számára, elkerülve a részletes vizsgálatot. ${ }^{21} \mathrm{~A}$ verbális intervenciók tehát egyre hangsúlyosabb szerepet kapnak a GVH gyakorlatában, az összes beavatkozás 31 százaléka ebbe a körbe tartozik, ennek megoszlását a 12. ábra mutatja.

A kapcsolódó versenykorlátozások kezelése kapcsán szükséges megjegyezni, hogy a GVH a fúziós eljárásokban - a Bizottsághoz illetve más versenyhatóságokhoz hasonlóan nem végzi el a kapcsolódó versenykorlátozások értékelését, ugyanakkor az elözetes egyeztetések során jelzi a felek számára, hogy mely korlátozások terjeszkedhetnek túl az elfogad- ható körön. A vállalkozások döntő többsége ennek eredményeként, hogy elkerülje a további eljárásokat, a kifogásolt korlátozásokat összhangba hozza a GVH gyakorlatával, így 2016 és 2020 között az esetek 75 százalékában elkerülhető volt a versenyfelügyeleti eljárás. Ezen időszakban összesen 3 esetben került sor versenyfelügyeleti eljárás indítására. Ezek közül végül kettőben született érdemi döntés a versenytanács részéről, melyekben a felek kötelezettségvállalására figyelemmel, a jogsértés vagy annak hiánya megállapítása nélkül előírta a felajánlott vállalások - ami a kifogásolt kikötések módosítását vagy törlését jelentette - teljesítését. ${ }^{22}$ Egy esetben pedig a szerződés időközbeni módosításra is tekintettel a GVH az eljárás vizsgálói szakaszban történő megszüntetéséről döntött. ${ }^{23}$ A nem kapcsolódó versenykorlátozások kezelését mutatja $a$ 13. ábra.

\section{VERBÁLIS INTERVENCIÓK MEGOSZLÁSA 2010 ÓTA}

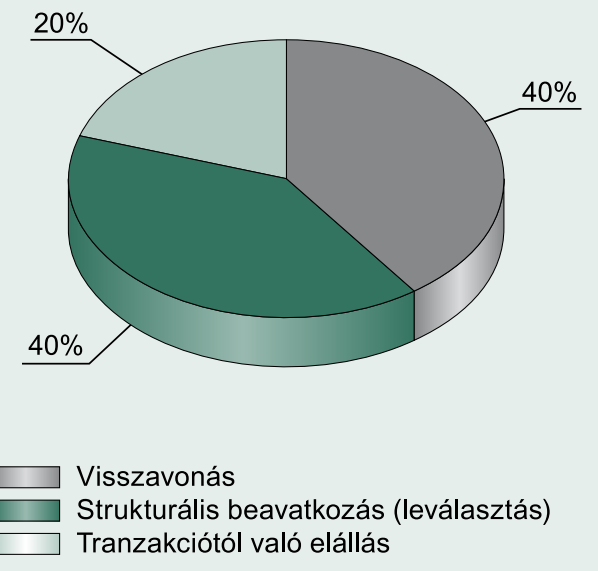

Forrás: saját szerkesztés 


\section{NEM KAPCSOLÓDÓ VERSENYKORLÁTOZÁSOK KEZELÉSE}

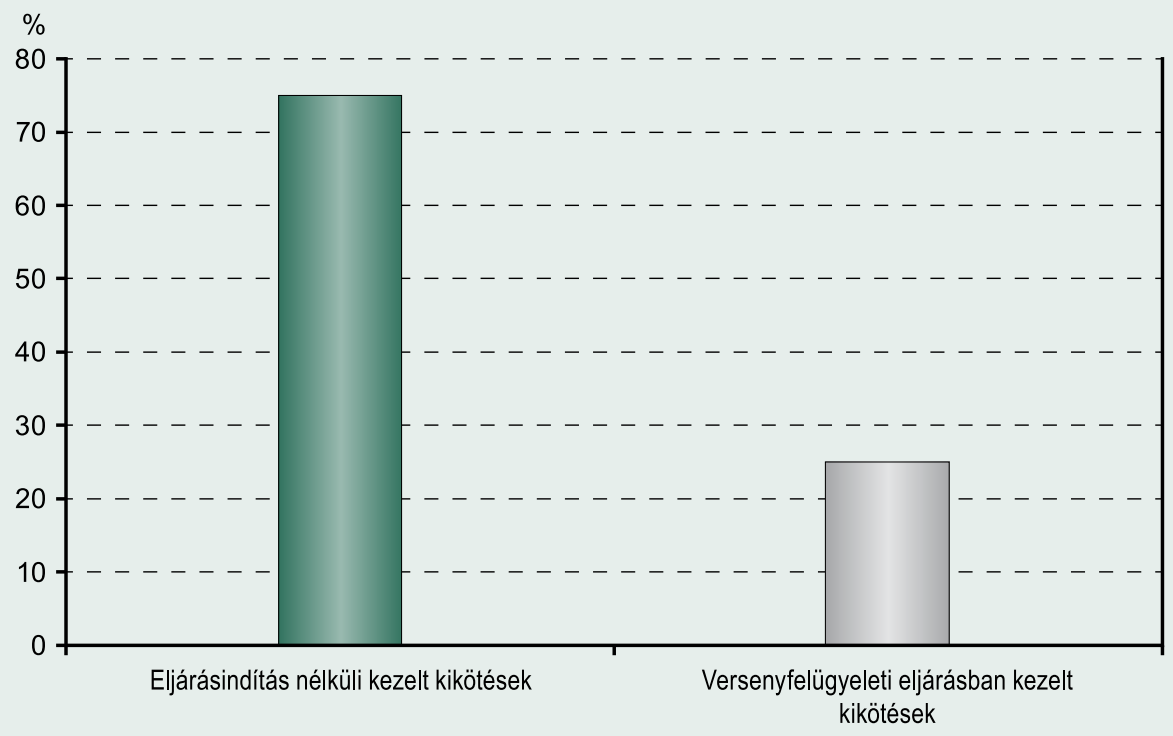

Forrás: saját szerkesztés

\section{EREDMÉNYEK ÖSSZEGZÉSE}

Összegzésként megállapítható, hogy a GVH a fúziós eljárásrendjének fejlesztése során három egymással is összefüggő szempont érvényesítésére törekedett: a vállalkozások terheinek csökkentésére, a fúziós ügyintézés kiszámíthatóságának, átláthatóságának javítására és az eljárások átfutási idejének rövidítésére az adathitelesség megőrzése mellett. Mivel egy működő rendszer fejlesztéséről volt szó, amelynek az átalakítás közben is az aktuális szabályokat betartva kellett ellátnia feladatát, ezért csak fokozatosan, lépésről-lépésre lehetett haladni, a már elvégzett lépések tapasztalatait feldolgozva, folyamatos újraértékelés és újratervezés mellett. Ez a folyamat a gyakorlatban igazolta Magyary Zoltán még mindig korszerünek ható gondolatait, miszerint a közigazgatás racionalizálása „nemcsak egyszeri munka, hanem állandó célt és speciális módszert igényel" és változatos eszközei közé tartozik „mindenekelött az állandó kritika a használt eljárások és megoldások felett" (Magyary, 1930, 175., 180.).

A fejlesztés lényeges egyik, nem számszerüsíthető eredménye, hogy az ügyintézés kiszámíthatósága és átláthatósága érdemben javult az elmúlt évtizedben, köszönhetően a fúziós bejelentések és döntések közzétételének, valamint a fúziós jogalkalmazáshoz kapcsolódó soft law dokumentumok intenzív bővítésének.

Arra vonatkozóan nem áll rendelkezésre becslés, hogy a fúziókontroll hatékonyságának javulása makroszinten (például a beruházásokra, a GDP-re) milyen számszerüsíthető hatásokkal járhatott, ugyanakkor a GVH a működéséből származó jóléti haszon mértékét rendszeresen elemzi. ${ }^{24} \mathrm{Ez}$ a hatásbecslés a versenykorlátozó megállapodásokkal, erőfölényes visszaélésekkel, valamint fúziókkal foglalkozó eljárások beavatkozásainak együttes hatásait értékeli, a legjobb nemzetközi becslé- 
si módszertanokat alkalmazva, szükségszerüen hozzávetőleges, de összességében nem túlzó eredményt biztosítva. A 2013-2018 időszakra vonatkozó ilyen becslés szerint a GVH beavatkozásainak köszönhetően a fogyasztók által megtakarított összeg több mint hatszorosa a GVH azonos időszaki teljes költségvetésének.

A fúziós eljárásrend elmúlt évtizedes fejlesztése ugyanakkor érdemi és pontosabban számszerüsíthető eredményekkel is járt. Az egyik legfontosabb eredménynek tekinthető az ügyintézés gyorsulása. A versenyhatásokkal nem járó, hatósági bizonyítvánnyal kezelhető fúziók - amelyek az elintézett ügyek nagy többségét, több mint 80 százalékát teszik ki - átlagos elintézési ideje ténylegesen 4 nap lett (ami ahhoz képest különösen szembetűnő, hogy 2010-ben az aggálymentes fúziók átlagos átfu- tási ideje több mint 100 nap volt). A 2010. évi adatokhoz képest a teljes körü fúziós eljárások átlagos ügyintézési ideje 2020-ra 62 százalékkal, az I. fázisú ügyek elintézési ideje 82,5 százalékkal csökkent. A fúziós ügyek ügyintézési határidejének 2009-2020 közötti alakulását a 14. ábra szemlélteti.

Az ábrán jól látható, hogy az egymásra épülő intézkedések hatására hogyan csökkent fokozatosan az ügyintézés tényleges átfutási ideje, ami így folyamatosan az adott időszakban érvényes törvényi határidő alatt volt (így például a hatósági bizonyítványok kiadására jelenleg a törvény 8 napot biztosít, miközben a tényleges átlagos elintézési idejük 4 nap).

Szintén konkrét eredménynek tekinthető, hogy a hatósági bizonyítvánnyal kezelhető tranzakciók igazgatási szolgáltatási díja 4 mil-

\section{AZ ÜGYINTÉZÉSI HATÁRIDÕ ALAKULÁSA FÚZIÓS ÜGYEKBEN 2009-2020 KÖZÖTT}

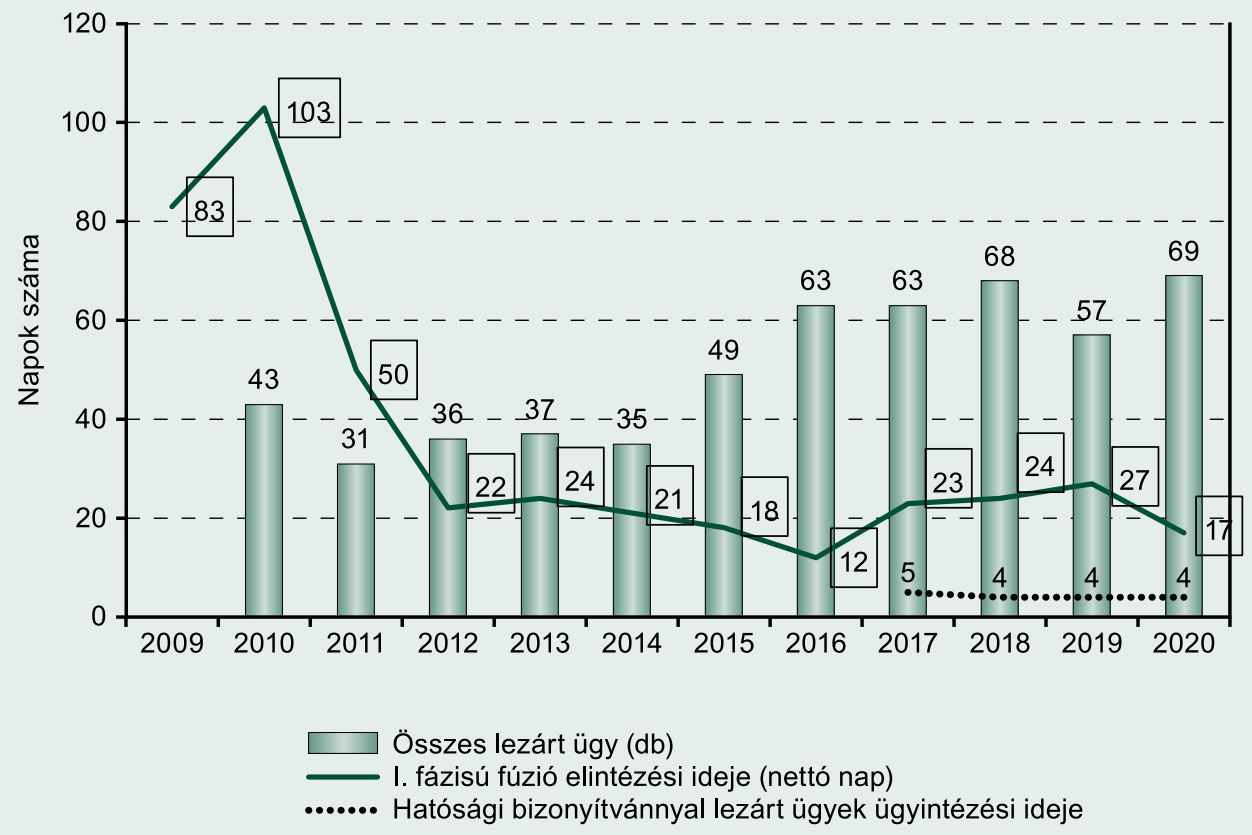

Forrás: saját szerkesztés 
lió forintról 1 millió forintra csökkent, ennek hatása, hogy a GVH fúziós eljárási díjbevételének kb. harmada (évi átlag 40-60 millió forintnyi összeg) a vállalkozásoknál marad.

A GVH 2018 óta lehetőséget biztosít a vállalkozások számára, hogy az összefonódás-bejelentéseket elektronikus formában nyújtsák be a GVH számára, azóta az elektronikusan benyújtott bejelentések aránya folyamatosan emelkedik, 2020-ban, a járványhelyzetben különösen segítette ez az ügyintézést, így ebben az évben már a bejelentések több mint 82 százaléka elektronikus formában került benyújtásra.

\section{JEGYZETEK}

${ }^{1}$ Erről részletesen lásd Tóth András: Hungarian experiences on the role of the competition policy in a transitional economy. Korea Economic Law Journal, ISSN: 1738-5458, Korea Economic Law Association, 2014, 13(3), pp. 123-138

2 VIssi Ferenc: A „Versenypolitika alapjai” előadássorozat, 2019. 03. 21.

3 Ezt árnyalja, hogy a bejelentési küszöbszámok közül az 500 millió forintos növekményi küszöb 1 milliárd forintra emelkedett a Tpvt. 2017. január 15-től hatályos módosításakor.

${ }^{4}$ Európai Unió Bírósága, 2009. július 16-i Der Grüne Punkt - Duales System Deutschland kontra Bizottság ítélet, C-385/07, EU:C:2009: 456, 186. pont, [EBHT 2009, I6155. oldal]

5 Közigazgatási és Igazságügyi Minisztérium (2011). Magyary Zoltán Közigazgatás-fejlesztési Program, „A Haza üdvére és a Köz szolgálatában” (Online: https://2010-2014.kormany.hu/hu/kozigazgatasies-igazsagugyi-miniszterium/hirek/magyaryprogram-a-koz-szolgalatara (letöltés ideje: 2021. 03. 29.)

6 Így például az Államreform Bizottság felállításáról szóló 1602/2014. (XI. 4.) Korm. határozat, a közigazgatási bürokráciacsökkentéssel összefüggésben egyes kormányrendeletek módosításáról szóló 441/2015. (XII. 28.) Korm. rendelet, a közigazgatási bürokráciacsökkentéssel összefüggő törvénymódosításokról szóló 2015. évi CLXXXVI. törvény.

7 A GVH 2011. évi beszámolója az Országgyülés részére, Online: https://gvh.hu/pfile/ file?path=/sajtoszoba/sajtokozlemenyek/sajtokozlemenyek/2012-es_sajtokozlemenyek/219832E D1EB4492D7.pdf\&inline=true (letöltés ideje: 2021. 03. 29.)

8 A fejlesztésről részletesen Tóth András: Fúziós eljárásjogunk fejlődése a Versenytanács elmúlt háromévi gyakorlata alapján. Versenytükör, 2013/2 (IX. évf. 2. szám) 19-33. oldal

9 A bejelentéses rezsim első tapasztalatai kapcsán lásd: Bodócsi András Az új fúziós rendszer bevezetése és első tapasztalatai. Versenytükör, 2017/2. (XIII. évf. 2. szám) 19-29. oldal

${ }^{10}$ A Fővárosi Törvényszék mint elsőfokú bíróság a VJ/31/2018. sz. versenyfelügyeleti eljárásban hozott határozat felülvizsgálata iránt indított perben hozott 107.K. 700.016/2019/11. számú ítélet 10. és 12. oldal

${ }^{11}$ A VJ/14/2017. sz. eljárásban a VJ/33/2016. sz. (Diófa Alapkezelő/EURO-MALL) ügyben, míg a VJ/15/2017. sz. eljárásban a VJ/1/2017. sz. 
(Infineon/Cree) ügyben hozott határozat került visszavonásra, majd az alapügyekben eljárási bírság kiszabásra.

${ }^{12}$ VJ/31/2018. sz. versenyfelügyeleti eljárás (DIGI/ Invitel ügy), az eredetileg kiszabott bírság 90 millió forint volt, amelyet a bírósági felülvizsgálatot követően a bíróságok jogerősen 45 millió forintra csökkentettek.

${ }^{13} \mathrm{VJ} / 43 / 2017$. sz. versenyfelügyeleti eljárás (DIGI/ Invitel ügy)

${ }^{14}$ A Tpvt. 32. $\$(1)$ bekezdése szerint a Gazdasági Versenyhivatal a 30 . $\$$ alapján hozott határozatát visszavonja akkor is, ha a közigazgatási bíróság által el nem bírált határozat a döntés szempontjából lényeges tény elhallgatásán vagy nem a valóságnak megfelelő közlésén (a továbbiakban együtt: félrevezető közlés) alapult. Erre vonatkozó eljárás az összefonódás végrehajtását követő 5 éven belül indítható meg.

${ }^{15} \mathrm{VJ} / 145 / 2015 ., \quad V J / 10 / 2016 ., \quad V J / 13 / 2016 .$, VJ/14/2016., VJ/13/2017., VJ/44/2017., VJ/23/2018., VJ/5/2020. és VJ/15/2020. sz. versenyfelügyeleti eljárások

${ }^{16}$ Ilyennek tekinthetők például a különböző szabadalomhoz való hozzáférést engedő vállalások.

${ }^{17}$ Ennek helyes értelmezéséhez ugyanakkor azt is hozzá kell tenni, hogy a fúziókontroll létezésének önmagában is van egy nem elhanyagolható megelőző szerepe, bizonyos tranzakciókba a vállalko- zások bele sem vágnak, mert már a saját előzetes értékelésük alapján nyilvánvaló számukra, hogy azt a versenyhatóság nem engedélyezné.

${ }^{18}$ A VJ/87/2016 sz., illetve a VJ/8/2020 sz. eljárás

${ }^{19}$ A kapcsolódó versenykorlátozások az összefonódást eredményező szerződésekben szereplő befektetésvédelmi célú és ezért elfogadható versenytilalmi vállalások (tipikus példa, hogy az eladó vállalja, legfeljebb 3 évig nem lép be arra a piacra, amelyen az értékesített vállalat aktív). A nem kapcsolódó versenykorlátozások tehát azok, amelyek túlterjeszkednek azon a körön, amely a befektetésvédelmi alapon, a vonatkozó joggyakorlat alapján elfogadható (például az eladó 10 évre vagy más piacokra vonatkozóan vállalt tartózkodása), így ezek már versenykorlátozó megállapodásként külön vizsgálhatók és szankcionálhatók.

${ }^{20}$ ÖB/8/2020. sz. (Stada/Walmak) összefonódás kapcsán egy gyógyszertermékhez kapcsolódó gyártási és forgalmazási jogok kerültek értékesítésre, megszüntetve ezzel a felmerülő horizontális versenyaggályt.

${ }^{21} \mathrm{VJ} / 45 / 2017$. sz. versenyfelügyeleti eljárás

${ }^{22}$ VJ/106/2014. és VJ/19/2019. sz. versenyfelügyeleti eljárások

${ }^{23}$ VJ/39/2017. sz. versenyfelügyeleti eljárás

${ }^{24}$ https://gvh.hu/gvh/elemzesek/tarsadalmi_haszon/ gvh_mukodesebol_szarmazo_joleti_haszon_ mertekerol (letöltés ideje: 2021. 03. 29.)

IRODALOM

Bodócsi A. (2017). Az új fúziós rendszer bevezetése és első tapasztalatai. Versenytükör 2017. II. 1929. oldal
BuráNSZKi J. (2020). A digitális piacokat érintő összefonódások vizsgálatainak tapasztalatai a Gazdasági Versenyhivatal legutóbbi ügyei során. Versenytükör 2020. II. 5-24. oldal 
MagYary Z. (1930). A magyar közigazgatás racionalizálása. A M. Kir. Miniszterelnök úr elé terjesztett javaslat. Királyi Magyar Egyetemi Nyomda, Budapest

Matolcsy Gy. (2020). A versenyképesség mint a fenntarthatóság meghatározó feltétele. Pénzügyi Szemle, LXV., 2020/2 különszám, 21. oldal

Tótн A. (2013). Fúziós eljárásjogunk fejlődése a Versenytanács elmúlt háromévi gyakorlata alapján. Versenytükör 2013. II. 19-33. oldal

Deloitte Riport (2020). M\&A Trends Survey: The future of M\&ADeal trends in a changing world. Online: https://www2.deloitte.com/content/dam/ Deloitte/us/Documents/mergers-acqisitions/usmergers-acquistions-trends-survey-the-future-m-a. pdf, letöltés ideje: 2021. 04. 21.

Európai Bizottság (2016). A piacok olajozott müködéséért, Versenypolitika, Az Európai Unió Kiadóhivatala, Luxembourg.
GVH (2020a). Közérthetően a magyar piaci versenyről. Gyorsjelentés a Gazdasági Versenyhivatal tevékenységéröl-2020

GVH (2020b). A GVH működéséből származó jóléti haszon mértékéről (ex ante impact assessment) Versenykorlátozó megállapodásokkal, erőfölényes visszaélésekkel, valamint fúziókkal foglalkozó eljárások 2013-2018 (2019-es árfolyamokkal frissítve)

KSH (2010). Makrogazdaság 2008-2009, Online: https://www.ksh.hu/docs/hun/xftp/idoszaki/makro/ makrogazdasag0809.pdf

KSH (2019). A bruttó hazai termék (GDP) értéke, volumenindexe és implicit árindexe (1995-), Online: https://www.ksh.hu/docs/hun/xstadat/ xstadat_eves/i_qpt001.html 